\title{
Cytotaxonomy of Parodon nasus and Parodon tortuosus (Pisces, Characiformes). A case of synonymy confirmed by cytogenetic analyses
}

\author{
Elisangela Bellafronte ${ }^{1}$, Vladimir Pavan Margarido ${ }^{2}$ and Orlando Moreira-Filho ${ }^{1}$ \\ ${ }^{1}$ Universidade Federal de São Carlos, Departamento de Genética e Evolução, São Carlos, SP, Brazil. \\ ${ }^{2}$ Universidade Estadual do Oeste do Paraná, Centro de Ciências Biológicas e da Saúde, Cascavel, \\ PR, Brazil.
}

\begin{abstract}
Morphological and cytogenetical studies were carried out on the freshwater fish Parodon nasus and Parodon tortuosus in order to evaluate a putative synonymy. The diploid chromosome number observed in both species was $2 \mathrm{n}=54(48 \mathrm{M} / \mathrm{SM}$ and $6 \mathrm{ST})$ with no differences between the sexes. Despite slight differences in the pattern of heterochromatin distribution and the number of cusps in symphysean teeth, the location of nucleolar organizer regions (NORs) and 5S rRNA genes (both species-specific features) were similar in both species. The remarkable similarity observed between these allopatric species supports recent taxonomical reviews indicating that $P$. tortuosus is a synonym for $P$. nasus.
\end{abstract}

Key words: cytogenetics, Parodontidae, systematics, 18S rDNA, 5S rDNA.

Received: July 7, 2004; Accepted: March 22, 2005.

\section{Introduction}

Over the last three decades, cytogenetic studies in Neotropical fishes have widely contributed to the taxonomy of Neotropical fishes. It has been pointed out that karyotypical analyses provides useful information for evolutionary and phylogenetic studies and aids in the identification of controversial species (Bertollo et al., 1986), and, indeed, such techniques have been successfully applied to characterize phenotypically similar cryptic species. Cytogenetical analyses of some fish species (e.g. from the genera Leporinus (Galetti et al., 1981a, b) and Brycon (Margarido and Galetti, 1996)) have agreed with their taxonomic status but cytogenetical studies of species such as Astyanax scabripinnis (Moreira-Filho and Bertollo, 1991), Hoplias malabaricus (Bertollo et al., 2000), Eigenmannia virescens (Almeida-Toledo et al., 2002) and Hoplerythrinus unitaeniatus (Diniz and Bertollo, 2003) have diverged from taxonomic classifications, suggesting that these groups should be taxonomically reviewed.

The Parodontidae, a relatively small freshwater fish family within the order Characiformes, comprises fish commonly known in Brazilian Portuguese as 'canivetes' or

Send correspondence to Orlando Moreira-Filho. Universidade Federal de São Carlos, Departamento de Genética e Evolução, Rodovia Washington Luís km 235, 13565-905 São Carlos, SP, Brazil. E-mail: omfilho@power.ufscar.br. 'charutos' ('penknives' or 'cheroots') (Pavanelli, 2003) which are widely distributed throughout nearly all South America. Three genera are reported for this family: Parodon Valenciennes, 1850; Apareiodon Eigenmann, 1916; and Saccodon Kner, 1964. Since 1849, 13 Apareiodon, 18 Parodon and 3 Saccodon species have been described for the Parodontidae, although after the detailed review of Pavanelli (2003) this number was reduced to a total of 21 species. Parodontid fish present distinct, nonoverlapping, reproductive periods (Barbieri et al., 1983) and a pale gray streamlined body (Nomura, 1979), the coloration being basically composed of stripes, bars and blotches providing an obliterative effect in their rocky and turbulent freshwater habitats (Sazima, 1980). The pectoral and pelvic fins of members of this family are well developed and adapted to stabilizing the fish on the rocky bottoms of the rivers and streams where these fish are usually found grazing on algae (Sazima, 1980).

Dentary structure is an important feature of the family Parodontidae and is helpful in the identification of the three genera (Garavello, 1977), small lateral teeth being present in the genus Parodon but absent in Apareiodon and Saccodon. In the Parodontidae the pre-maxilla is surrounded by a series of tiny teeth with rounded cusps, the number of cusps of pre-maxilla teeth being a reliable character for the diagnosis of Parodon and Apareiodon species but not for Saccodon species, which are characterized by extensive teeth polymorphism (Garavello, 1977). 
Cytogenetic analyses carried out on 12 species of Parodontidae (Table 1) have shown a conserved diploid number of $2 \mathrm{n}=54$ chromosomes but differences related to karyotypical structure. A multiple sex chromosome $\mathrm{ZZ} / \mathrm{ZW}_{1} \mathrm{~W}_{2}$ type system has been reported for Apareiodon affinis (Moreira-Filho et al., 1980) but a ZZ/ZW sex chromosome system for Parodon hilarii (Moreira-Filho et al., 1993), Parodon sp. (Centofante et al., 2002) and Apareiodon sp. (Margarido et al., 2004).

Britski (1972) states that Parodon tortuosus Eigenmann and Norris, 1900 (type locality Tietê river, Upper Paraná basin, São Paulo state, Brazil) is the only species of this genus in the Paraná river basin, whereas Parodon nasus Kner, 1859 (type locality Cuiabá river, Paraguay river basin, Mato Grosso, Brazil) is restricted to the Paraguay river basin (Britski et al., 1999). However, the taxonomical review performed by Pavanelli (2003) considered $P$. tortuosus to be a junior synonym for $P$. nasus.

The aim of the work described in the present paper was to better characterize $P$. tortuosus and $P$. nasus using both cytogenetic analysis and a comparative analysis of the number of teeth cusps in these two taxonomic units.

\section{Material and Methods}

Specimens of $P$. tortuosus were collected in the Passa-Cinco river (Upper Paraná river basin) and P. nasus in the Cuiabá river (Paraguay river basin). Mitotic chromosomes were obtained from 20 specimens (10 males and 10

Table 1 - An overview of karyotypical data in Parodontidae species.

\begin{tabular}{|c|c|c|c|c|c|c|c|c|}
\hline Species & Locality & Sex & $2 n$ & Chromosome formulae & FN & Sex system & NORs & Ref \\
\hline \multicolumn{9}{|l|}{ Parodon } \\
\hline \multirow[t]{4}{*}{ P. tortuosus } & Passa-Cinco River, SP & F-M & 54 & $48 \mathrm{M} / \mathrm{SM}, 6 \mathrm{ST}$ & 108 & - & Pair n. 25(ST) & 1 \\
\hline & Ivaí River, PR & M & 54 & - & 108 & - & - & 2 \\
\hline & Tibagi River, PR & F-M & 54 & $54 \mathrm{M} / \mathrm{SM}$ & - & - & - & 3 \\
\hline & Paiol Grande stream, SP & F-M & 54 & $48 \mathrm{M} / \mathrm{SM}, 6 \mathrm{ST}$ & 108 & - & Pais n. 25 (ST) & 4 \\
\hline P. pongoensis & Araguaia River, MT & F-M & 54 & $50 \mathrm{M} / \mathrm{SM}, 4 \mathrm{ST}$ & 108 & - & Pair n. 2 (SM) & 5 \\
\hline \multirow[t]{2}{*}{ P. hilarii } & Porta stream, MG & $\mathrm{F}$ & 54 & $53 \mathrm{M} / \mathrm{SM}, 1 \mathrm{ST}$ & 108 & $\mathrm{ZW}$ & Pair n. 15 (SM) & 6 \\
\hline & & M & 54 & $54 \mathrm{M} / \mathrm{SM}$ & 108 & $\mathrm{ZZ}$ & Pair n. 15 (SM) & \\
\hline \multirow[t]{2}{*}{ Parodon sp. } & Paiol Grande stream, SP & $\mathrm{F}$ & 54 & $54 \mathrm{M} / \mathrm{SM}$ & 108 & $\mathrm{ZW}$ & Pair n. 15 (SM) & 7 \\
\hline & & M & 54 & $54 \mathrm{M} / \mathrm{SM}$ & 108 & $\mathrm{ZZ}$ & Pair n. 15 (SM) & \\
\hline \multicolumn{9}{|l|}{ Apareiodon } \\
\hline \multirow[t]{3}{*}{ A. .ibitiensis } & Passa-Cinco River, SP & F-M & 54 & $50 \mathrm{M} / \mathrm{SM}, 4 \mathrm{ST}$ & 108 & - & Pair n. 26 (ST) & 8 \\
\hline & Ivaí River, PR & $\mathrm{M}$ & 54 & $50 \mathrm{M} / \mathrm{SM}, 4 \mathrm{ST}$ & 108 & - & - & 9 \\
\hline & Tibagi River, PR & F-M & 54 & $52 \mathrm{M} / \mathrm{SM}, 2 \mathrm{ST}$ & 108 & - & - & 10 \\
\hline \multirow[t]{2}{*}{ Apareiodon sp. } & Piquiri River, PR & $\mathrm{F}$ & 54 & $50 \mathrm{M} / \mathrm{SM}, 4 \mathrm{ST}$ & 108 & $\mathrm{ZW}$ & Pair n. 26 (ST) & 11 \\
\hline & & $\mathrm{M}$ & 54 & $50 \mathrm{M} / \mathrm{SM}, 4 \mathrm{ST}$ & 108 & $\mathrm{ZZ}$ & Pair n. 26 (ST) & \\
\hline \multirow[t]{2}{*}{ A. piracicabae } & Passa-Cinco/Mogi-Guaçu & F-M & 54 & $52 \mathrm{M} / \mathrm{SM}, 2 \mathrm{ST}$ & 108 & - & Pair n. 27 (ST) & 12 \\
\hline & Rivers, SP & M & 55 & $52 \mathrm{M} / \mathrm{SM}, 2 \mathrm{ST}, 1 \mathrm{~B}$ & 110 & - & - & 13 \\
\hline Apareiodon sp. A & Passa-Cinco River, SP & F-M & 54 & $50 \mathrm{M} / \mathrm{SM}, 4 \mathrm{ST}$ & 108 & - & Pair n. 26 (ST) & 14 \\
\hline Apareiodon sp. B & Frio stream, MG & F-M & 54 & $50 \mathrm{M} / \mathrm{SM}, 4 \mathrm{ST}$ & 108 & - & Pair n. 26 (ST) & 15 \\
\hline Apareiodon sp. C & Barreiro stream, MG & $\mathrm{M}$ & 54 & $52 \mathrm{M} / \mathrm{SM}, 2 \mathrm{ST}$ & 108 & - & - & 16 \\
\hline A. vittatus & Araguaia River, MT & F-M & 54 & $52 \mathrm{M} / \mathrm{SM}, 2 \mathrm{ST}$ & 108 & - & Pair n. 27 (ST) & 17 \\
\hline \multirow[t]{2}{*}{ A. affinis } & Iguaçu River, PR & $\mathrm{F}$ & 55 & $51 \mathrm{M} / \mathrm{SM}, 4 \mathrm{ST}$ & 110 & - & Pair n. 26 (ST) & 18 \\
\hline & Passa-Cinco, Mogi-Guaçu and & M & 54 & $50 \mathrm{M} / \mathrm{SM}, 4 \mathrm{ST}$ & 108 & - & Pair n. 26 (ST) & \\
\hline \multirow[t]{10}{*}{ A. affinis } & Piracicaba Rivers, SP & F-M & 54 & $\mathrm{a}=50 \mathrm{M} / \mathrm{SM}, 4 \mathrm{ST}$ & 107 & - & Pair n. 26 (ST) & 19,20 \\
\hline & Lower Paraná basin (Argentina) & $\mathrm{M}$ & 54 & $\mathrm{~b}=50 \mathrm{M} / \mathrm{SM}, 2 \mathrm{ST}, 2 \mathrm{~A}$ & 106 & - & Pair n. 26 (ST) & \\
\hline & & F-M & 54 & $\mathrm{c}=50 \mathrm{M} / \mathrm{SM}, 3 \mathrm{ST}, 1 \mathrm{~A}$ & 107 & - & Pair n. 26 (1ST, 1A) & \\
\hline & & F-M & 54 & $\mathrm{~d}=50 \mathrm{M} / \mathrm{SM}, 2 \mathrm{ST}, 2 \mathrm{~A}$ & 106 & - & - & \\
\hline & & F-M & 54 & $\mathrm{e}=50 \mathrm{M} / \mathrm{SM}, 1 \mathrm{ST}, 3 \mathrm{~A}$ & 105 & - & - & \\
\hline & & F-M & 54 & $\mathrm{f}=50 \mathrm{M} / \mathrm{SM}, 2 \mathrm{ST}, 2 \mathrm{~A}$ & 98 & - & - & \\
\hline & & F-M & 54 & $\mathrm{~g}=50 \mathrm{M} / \mathrm{SM}, 1 \mathrm{ST}, 3 \mathrm{~A}$ & 105 & - & Pair n. $26(2 \mathrm{~A})$ & \\
\hline & & F-M & 54 & $\mathrm{~h}=50 \mathrm{M} / \mathrm{SM}, 4 \mathrm{~A}$ & 104 & - & - & \\
\hline & & F-M & 54 & $\mathrm{i}=49 \mathrm{M} / \mathrm{SM}, 5 \mathrm{~A}$ & 103 & - & - & \\
\hline & & F-M & 54 & $\mathrm{j}=48 \mathrm{M} / \mathrm{SM}, 6 \mathrm{~A}$ & 102 & - & - & \\
\hline \multirow[t]{2}{*}{ A. affinis } & Cuiabá River, MT & F-M & 54 & $\mathrm{a}=42 \mathrm{M} / \mathrm{SM}, 12 \mathrm{ST} / \mathrm{A}$ & 98 & - & Pair n. 23 & 21 \\
\hline & & F-M & 54 & $\mathrm{~b}=44 \mathrm{M} / \mathrm{SM}, 10 \mathrm{ST} / \mathrm{A}$ & 102 & - & - & 22 \\
\hline \multirow[t]{2}{*}{ A. affinis } & Tibagi River, PR & $\mathrm{F}$ & 55 & - & - & $\mathrm{ZW}_{1} \mathrm{~W}_{2}$ & - & 23 \\
\hline & & M & 54 & - & - & $\mathrm{ZZ}$ & - & \\
\hline \multirow[t]{2}{*}{ A. affinis } & Paraná River, Porto Rico, PR & $\mathrm{F}$ & 55 & - & & $\mathrm{ZW}_{1} \mathrm{~W}_{2}$ & - & 24 \\
\hline & & $\mathrm{M}$ & 54 & - & & $\mathrm{ZZ}$ & - & \\
\hline \multirow{2}{*}{ A. cf. affinis } & Rio Sapucaí, MG & $\mathrm{F}$ & 55 & - & & $\mathrm{ZW}_{1} \mathrm{~W}_{2}$ & - & 25 \\
\hline & & $\mathrm{M}$ & 54 & - & & $\mathrm{ZZ}$ & - & \\
\hline
\end{tabular}

Legend: 2n (diploid number), FN (fundamental number), NOR (nucleolar organizer regions), F (female), M (male), M/SM (metacentric/submetacentric), ST/A (subtelocentric/acrocentric). Reference: 1 - Moreira-Filho et al. (1984, 1985), Jesus and Moreira-Filho (2000a); 2 - Sato et al. (1998); 3 - Schneider and Dias (2002b); 4 - Centofante et al. (2002); 5 - Jesus and Moreira-Filho (2000a); 6 - Moreira-Filho et al. (1993), Jesus and Moreira-Filho (2000a); 7 Centofante et al. (2002); 8 - Moreira-Filho et al. (1984, 1985), Jesus and Moreira-Filho (2000a); 9 - Sato et al. (1998); 10 - Schneider and Dias (2000); 11 - Margarido et al. (2004); 12 - Moreira-Filho et al. (1984, 1985), Jesus and Moreira-Filho (2000b); 13 - Falcão et al. (1984); 14 - Jesus and Moreira-Filho (2000b); 15 - Jesus and Moreira-Filho (2000b); 16 - Jesus and Moreira-Filho (2000b); 17 - Jesus and Moreira-Filho (2000b); 18 - Moreira-Filho et al. (1980, 1984, 1985), Jesus and Moreira-Filho (1999), Jorge and Moreira-Filho (2000); 19 - Jorge and Moreira-Filho (2000); 20 - Jorge (2000); 21 - Jesus and Moreira-Filho (1999); 22 - Jesus (1996); 23 - Schneider and Dias (2002a); 24 - Endo and Júlio Jr. (2001); 25 - Leite and Maistro (2000). 
females) of $P$. nasus and 22 specimens (8 males and 14 females) of $P$. tortuosus using the methodology described by Bertollo et al. (1978). Silver nitrate (Ag) staining was used to detect the nucleolar organizer regions (Ag-NORs) according to the method of Howell and Black (1980). Fluorescent in situ hybridization (FISH) with 18S rDNA probes obtained from Prochilodus argenteus (Hatanaka and Galetti, 2004) was performed according to the protocol of Pinkel et al. (1986). This same procedure was employed for FISH with a 5SDNA probe obtained from Leporinus elongatus (Martins and Galetti, 1999). Differentiation of GC-rich chromosome regions was carried out by Schmid's method (Schmid, 1980) followed by staining with the GCspecific fluorochrome Chromomycin $\mathrm{A}_{3}$, and the constitutive heterochromatin being analyzed by the C-banding technique (Sumner, 1972). The chromosome types were classified according their arm ratio, as proposed by Levan et al. (1964). The teeth cusps analyses were carried out on 23 specimens of $P$. tortuosus and 33 specimens of $P$. nasus according to the methodology described by Moreira-Filho and Garavello (1994).

\section{Results}

The $P$. tortuosus karyotype was $2 \mathrm{n}=54(48 \mathrm{M} / \mathrm{SM}+$ 6ST) for both sexs (Figure 1-a), C-banding showing evident pericentromeric marks on chromosome pairs $2,4,10$, 11 and 19 as well as telomeric blocks on pairs $1,6,7,17,25$, 26 and 27 (Figure 2-a).

This paper presents for the first time a cytogenetical analyses of $P$. nasus, the diploid number obtained by us being $2 \mathrm{n}=54(48 \mathrm{M} / \mathrm{SM}+6 \mathrm{ST})$ for both sexes (Figure 1-b), $\mathrm{C}$-banding showing conspicuous pericentromeric bands on chromosome pairs 4, 5, 16 and telomeric blocks on pairs 1 , 6, 17, 25, 26 and 27 (Figure 2-b).

A single Ag-NOR pair was found in both P. nasus and $P$. tortuosus, located at the terminal position on the long arm of the $25^{\text {th }}$ chromosome pair (Figure 1). Four GC-rich signals were observed for both species, two on the short arms and two on the long arms (coincident with the NOR sites) of chromosome pair 25 (Figure 1). A single NOR pair on the long arms of chromosome pair 25 was confirmed by FISH with the $18 \mathrm{~S}$ rDNA probe (Figure $3 \mathrm{a}-\mathrm{b}$ ). However, while 5S rDNA FISH showed regions in a single pair on $P$. tortuosus chromosomes, this probe showed regions on three $P$. nasus chromosomes (Figure $3 \mathrm{c}-\mathrm{d}$ ).

The number of symphysean teeth cusps ranged from 16 to 19 in $P$. tortuosus (Figures 4-a, 5) and from 17 to 21 in $P$. nasus (Figures 4-b, 5).

\section{Discussion}

The results obtained for diploid number $(2 n=54)$, karyotype formulae, NORs, GC-rich regions, C-banding and $5 \mathrm{~S}$ rDNA location were quite similar in P. tortuosus and $P$. nasus. Our $P$. tortuosus data supports that previously

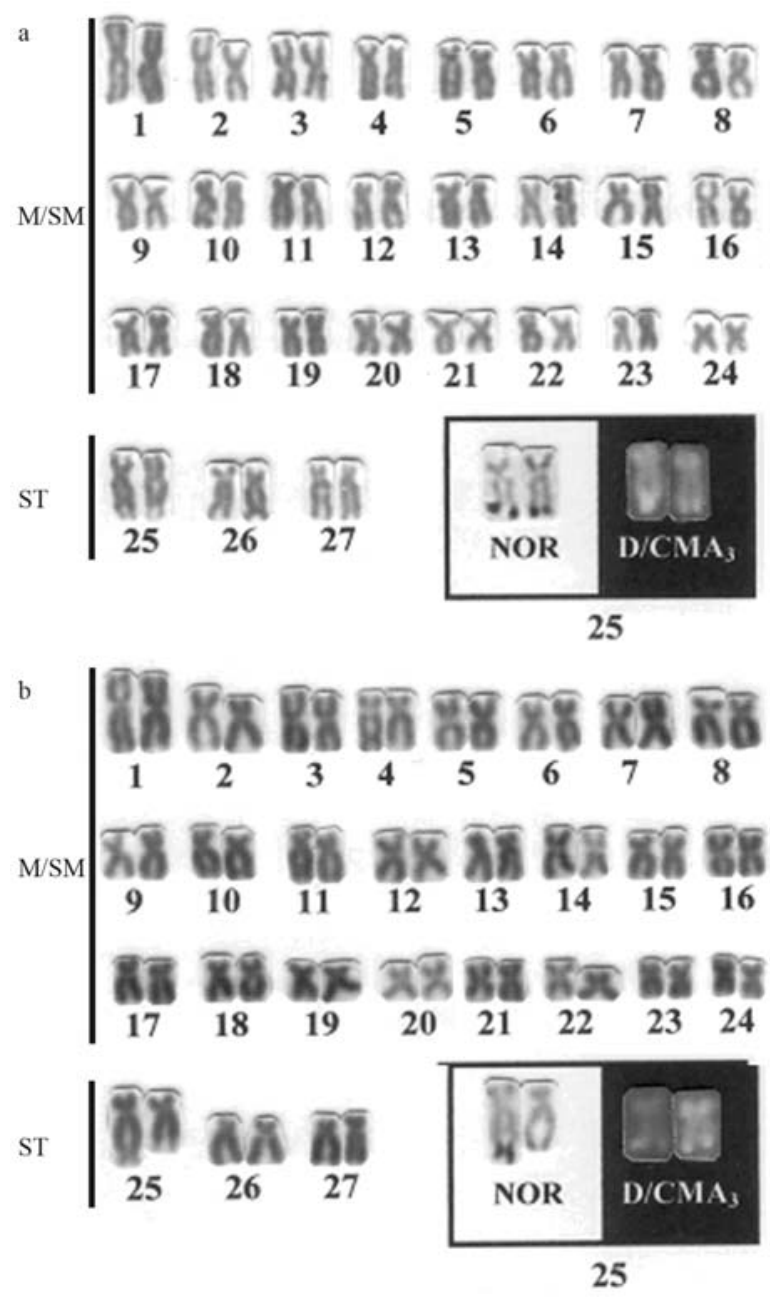

Figure 1 - Karyotypes of: a. Parodon tortuosus and b. Parodon nasus with conventional Giemsa staining. The nucleolar organizer regions after silver nitrate (Ag-NOR) and $\mathrm{D} / \mathrm{CMA}_{3}$ staining are showed in the boxes.

published by Moreira-Filho et al. (1984, 1985), Jesus and Moreira-Filho (2000a), Vicente et al. (2001) and Centofante et al. (2002). A diploid number of 54 has been reported for all Parodontidae species (Table 1), with the exception of $A$. affinis females from Upper Paraná which present a female heterogamety characterized by a multiple $\mathrm{ZW}_{1} \mathrm{~W}_{2}$ sex chromosome system. While Apareiodon species present extensive karyotypical similarity (MoreiraFilho et al., 1985), a diversification of chromosomal morphology is found within the genus Parodon, with a ZZ/ZW sex chromosome system distinguishing $P$. hilarii and Parodon sp. from the other species of this genus (Centofante et al., 2002).

A single NOR-bearing chromosomal pair has been found in Parodontidae fish (Table 1). The location of the NOR seems to be more conserved within Apareiodon, except that $A$. piracicabae shows intra- and inter-individual polymorphism related to the occurrence of double NORs in 
each chromosome of a subtelocentric pair (Moreira-Filho et al., 1984).

The NORs of $P$. hilarii, $P$. pongoensis (also known as Parodon sp.) and P. tortuosus have been considered to be species-specific markers located on different chromosomes (Jesus and Moreira-Filho, 2000a), and our results show that the NORs of both $P$. tortuosus and $P$. nasus are located on the same chromosomal pair, reinforcing the idea of synonymy between these two species.

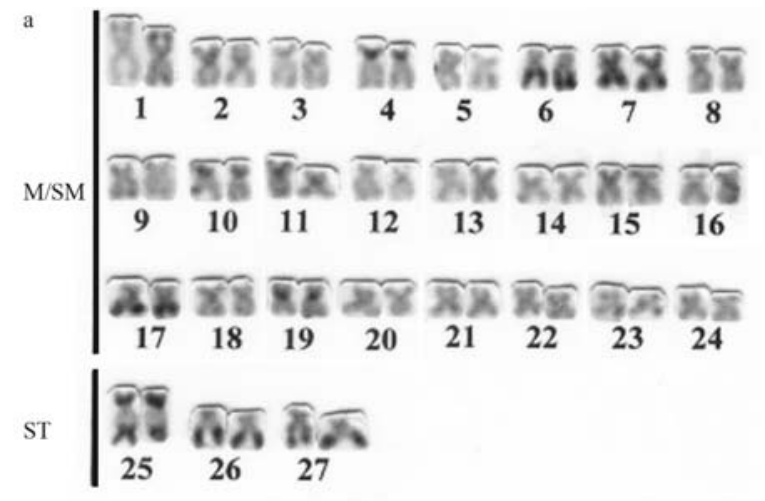

Chromomycin $\mathrm{A}_{3}$ staining showed that the NORs of $P$. tortuosus and $P$. nasus were GC-rich, a result identical to those published for other Parodontidae species (Jesus, 1996). The distribution of constitutive heterochromatin in Parodon and Apareiodon chromosomes occurs preferentially at the centromeric and, sometimes, the telomeric regions (Jesus and Moreira-Filho, 2000b). Our C-banding results were quite similar for $P$. tortuosus and $P$. nasus, with slight differences found in only a few chromosomes.

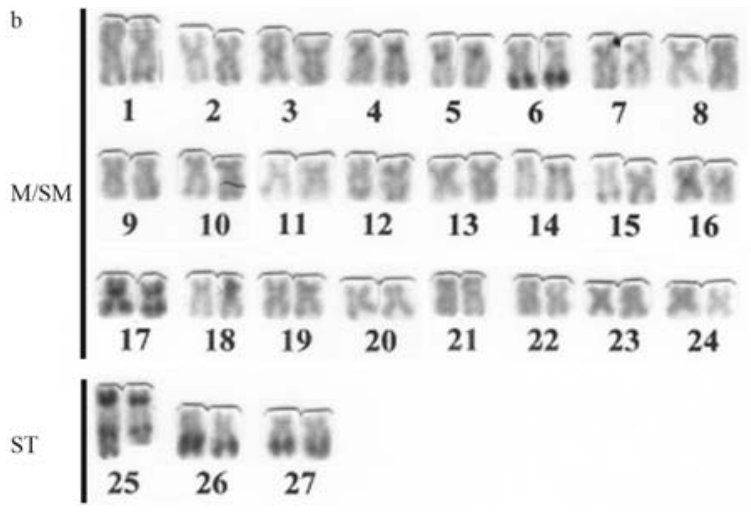

Figure 2 - C-banded karyotypes of: a. Parodon tortuosus and b. Parodon nasus.
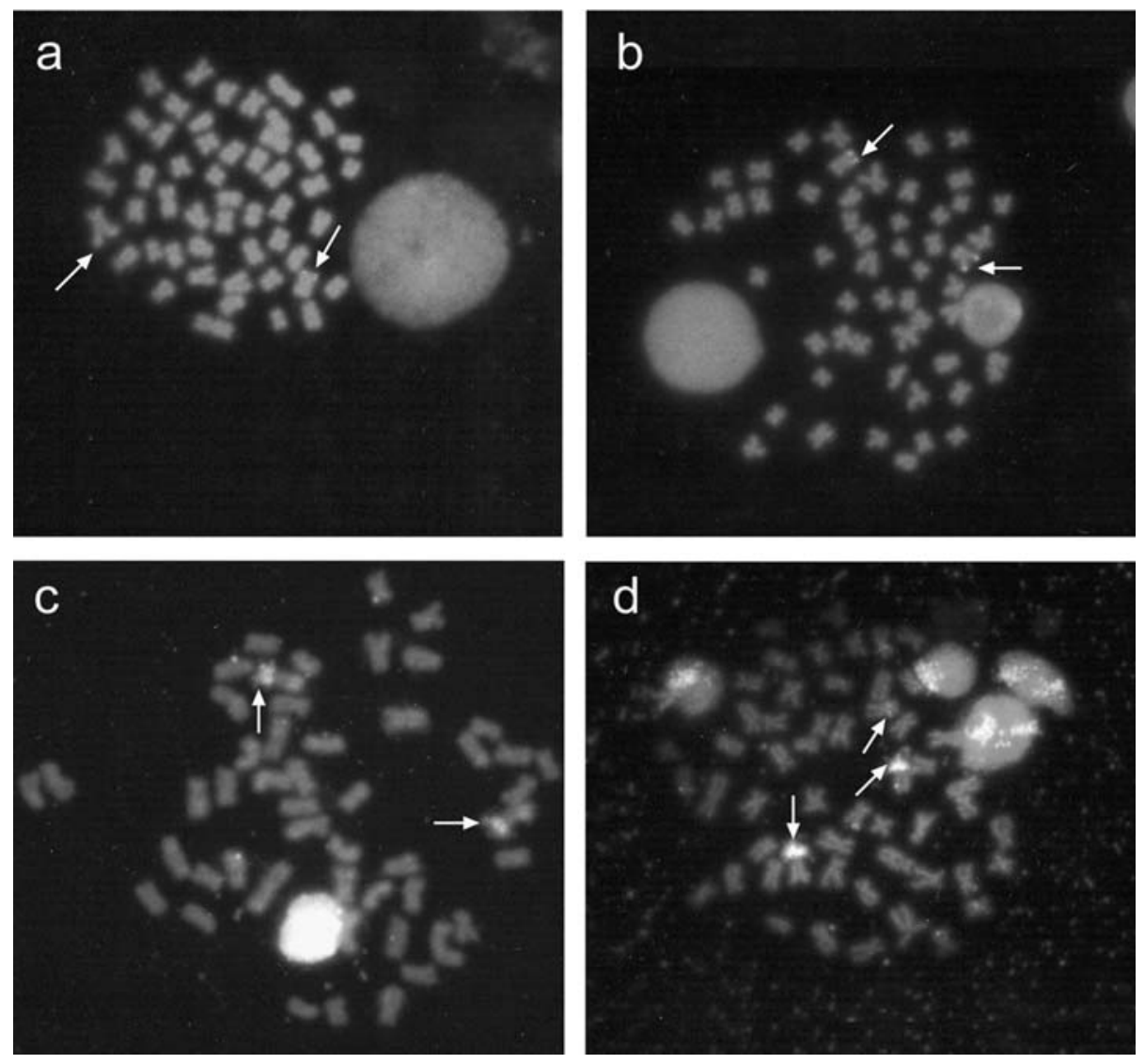

Figure 3 - Fluorescent in situ hybridization with the 18S rDNA probe (a. Parodon tortuosus and b. Parodon nasus) and the 5S rDNA probe (c. Parodon tortuosus and d. Parodon nasus). 


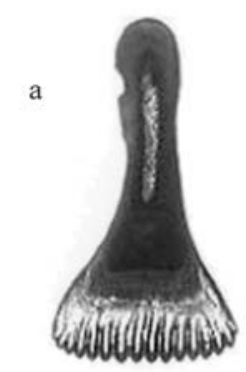

16

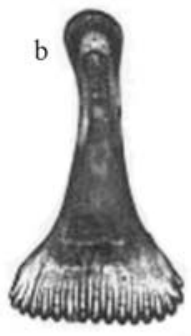

17

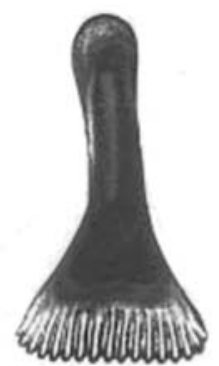

17

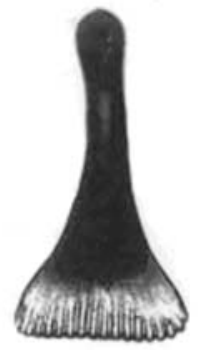

18

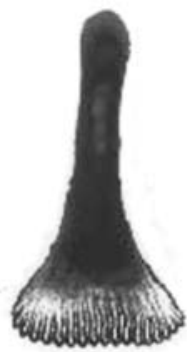

19

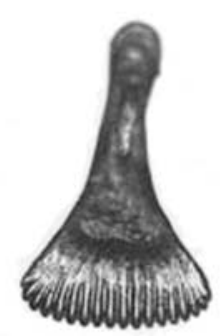

18

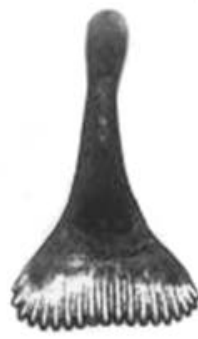

19

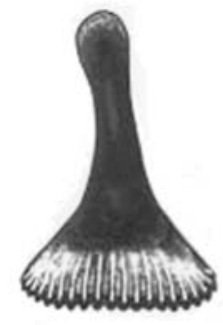

20

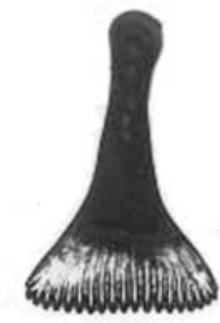

21

$0.5 \mathrm{~mm}$

Figure 4 - Symphysean teeth of: a. Parodon tortuosus and b. Parodon nasus, with the variation of the number of cusps for each species.

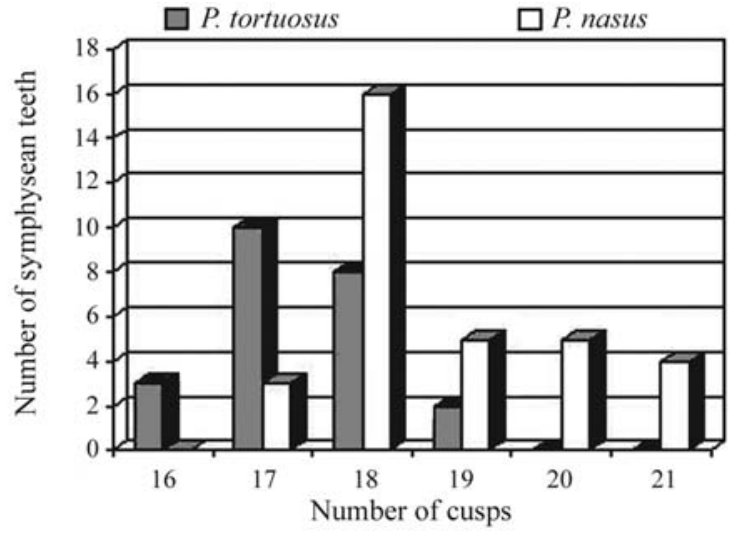

Figure 5 - Histogram showing the distribution of frequency of cusps by teeth in P. tortuosus (grey) and in P. nasus (white).

These slight differences have also been observed in $P$. tortuosus by other authors (Jesus and Moreira-Filho, 2000a; Vicente, 2001; Centofante et al., 2002) and also in $P$. hilarii (Jesus, 1996; Vicente, 2001), and are probably related to technical artifacts and/or interpopulation differences. These observations lead us to conclude that in the family Parodontidae the pattern of constitutive heterochromatin cannot be considered a useful marker for species diagnosis, contrasting with the situation in the genera Leporinus (Galetti et al., 1991a) and Brycon (Margarido and Galetti, 1996) where the C-banding pattern is species-specific.
Vicente et al. (2001) detected a major and a minor 5S rDNA cluster on distinct chromosomal pairs of $P$. hilarii, $P$. pongoensis and $P$. tortuosus providing a species-specific marker. The occurrence of 5S rRNA genes in clusters involving more than a single chromosomal pair has been reported in several fish species, including those from the genera Schizodon (Martins and Galetti, 2000), Leporinus (Martins and Galetti, 1999) and Brycon (Wasko and Galetti, 2001). In these species, as in Parodon, besides the presence of two clusters there are also differences related to the location of $18 \mathrm{~S}$ and $5 \mathrm{~S}$ rDNA, which seems to represent a common situation in fish (Martinez et al., 1996). According to Martins and Galetti (1999), this distinctive location of ribosomal genes is required for the efficient maintenance of the conserved sequence displayed in tandem arrays.

We found that in P. nasus and P. tortuosus only the 5S rDNA major cluster was well-defined and on the same chromosome (syntenic) as the NORs, similar to the situation in Salmo salar described by Pendás et al. (1994). Since $P$. tortuosus is the only species within the genus Parodon to present such a feature, our results concerning the location of the 5S rDNA major clusters reinforces the similarity between $P$. nasus and $P$. tortuosus. In $P$. nasus, however, a third chromosome also contained the $5 \mathrm{~S}$ rDNA major cluster, probably representing a homologue from a second $5 \mathrm{~S}$ rDNA-bearing pair (a minor cluster) absent from the $P$. tortuosus specimens analyzed by us. The small size of these clusters (i.e. only a few copies of the 5S rRNA genes) in $P$. nasus may have been why this homologue was not detected by FISH, as it was reported for the genus Brycon (Wasko and Galetti, 2001). 
Our morphological analyses based on the number of symphysean teeth cusps showed a variation of 16-19 for $P$. tortuosus and 17-21 for P. nasus. According to Jesus and Moreira-Filho (2000a) such an overlap in the number of cusps is uncommon among Parodon species, although a symphysean teeth analyses of some Parodontidae species has shown a similar number of cusps in distinct species such as Apareiodon ibitiensis and Apareiodon sp. which were found to have 8-11 cusps (Jesus, 1996).

Taken together, our results demonstrate a high degree of similarity between $P$. tortuosus from the Passa-Cinco river and $P$. nasus from the Cuiabá river, supporting the taxonomical review carried out by Pavanelli (2003) who states that $P$. tortuosus should be considered a synonymy for P. nasus.

\section{Acknowledgments}

This study was supported by the Brazilian agency Coordenadoria de Aperfeiçoamento de Pessoal de Nível Superior (CAPES).

\section{References}

Almeida-Toledo LF, Daniel-Silva MFZ, Moysés CB, Fonteles SBA, Lopes CE, Akama A and Foresti F (2002) Chromosome evolution in fish: Sex chromosome variability in Eigenmannia virescens (Gymnotiformes, Sternopygidae). Cytogenet Gen Res 99:164-169.

Barbieri G, Verani JR and Barbieri MC (1983) Análise do comportamento reprodutivo das espécies Apareiodon affinis (Steindachner, 1879), Apareiodon ibitiensis Campos, $1944 \mathrm{e}$ Parodon tortuosus Eigenmann and Norris, 1900 do Rio Passa-Cinco, Ipeúna, SP (Pisces, Parodontidae). Anais do III Seminário Regional de Ecologia, São Carlos, SP, pp 189199.

Bertollo LAC, Takahashi CS and Moreira-Filho (1978) Cytotaxonomic considerations on Hoplias lacerdae (Pisces, Erythrinidae). Brazil J Genet 1:103-120.

Bertollo LAC, Moreira-Filho O and Galetti Jr. PM (1986) Cytogenetics and taxonomy: Considerations based on chromosome studies of freshwater fish. J Fish Biol 28:153-159.

Bertollo LAC, Born GG, Dergam JA, Fenocchio AS and Moreira-Filho O (2000) A biodiversity approach in the neotropical Erythrinidae fish, Hoplias malabaricus. Karyotypic survey, geographic distribution of cytotypes and cytotaxonomic considerations. Chromosome Res 8:603-613.

Britski HA (1972) Peixes de água doce do Estado de São Paulo. Sistemática. In: Comissão Interestadual da Bacia ParanáUruguai. Poluição e Piscicultura. Boletim do Instituto de Pesca, Faculdade de Saúde Pública da USP, São Paulo, pp 79-108.

Britski HA, Silimon KZ and Lopes BS (1999) Peixes do Pantanal. Manual de Identificação. 1 edição. Embrapa-SPI, Corumbá, $184 \mathrm{p}$.

Centofante L, Bertollo LAC and Moreira-Filho O (2002) A ZZ/ZW sex chromosome system in a new species of the genus Parodon (Pisces, Parodontidae). Caryologia 55:139150 .
Diniz D and Bertollo LAC (2003) Karyotypic studies on Hoplerythrinus unitaeniatus (Pisces, Erythrinidae) populations. A biodiversity analysis. Caryologia 56:303-313.

Endo KS and Júlio Jr. HF (2001) Análises citogenéticas de Apareiodon affinis (Pisces, Parodontidae) da Planície de inundação do Rio Paraná. $47^{\circ}$ Congresso Nacional de Genética, Águas de Lindóia, SP, Cd-Rom.

Falcão JN, Moreira-Filho O and Bertollo LAC (1984) An adittional chromosome in two fish species. Brazil J Genet 7:109-118.

Galetti Jr. PM, Foresti F, Bertollo LAC and Moreira-Filho O (1981a) Karyotypic similarity in three genera (Leporinus, Leporellus and Schizodon) of the family Anostomidae (Pisces, Teleostei). Brazil J Genet 4:11-15.

Galetti Jr. PM, Foresti F, Bertollo LAC and Moreira-Filho O (1981b) Heteromorphic sex chromosomes in three species of the genus Leporinus (Pisces, Anostomidae). Cytogenet Cell Genet 29:138-142.

Galetti Jr. PM, César ACG and Vênere PC (1991) Heterochromatin and NORs variability in Leporinus fish (Anostomidae, Characiformes). Caryologia 44:287-292.

Garavello JC (1977) Descrição de Apareiodon vittatus sp. n. do Rio Iguaçu e comentários sobre as espécies do gênero Apareiodon Eigenmann, 1916 (Ostariophysi, Parodontidae). Rev Brasil Biol 37:447-455.

Hatanaka T and Galetti Jr PM (2004) Mapping 18S and 5S ribosomal RNA genes in the fish Prochilodus argenteus Agassiz, 1929 (Characiformes, Prochilodontidae). Genetica 122:239-244.

Howell WM and Black DA (1980) Controlled silver-staining of nucleolus organizer regions with a protective colloidal developer: A 1-step method. Experientia 36:1014-1015.

Jesus CM (1996) Contribuições aos estudos citogenéticos da família Parodontidae (Pisces, Characiformes). MSc Dissertation, Universidade Federal de São Carlos, São Carlos.

Jesus CM and Moreira-Filho O (1999) Comparative cytogenetics in Apareiodon affinis (Pisces, Characiformes) and considerations regarding diversification of the group. Genetica 105:63-67.

Jesus CM and Moreira-Filho O (2000a) Karyotypes of three species of Parodon (Teleostei, Parodontidae). Icththyol Explor Freshwaters 11:75-80.

Jesus CM and Moreira-Filho O (2000b) Cytogenetic studies in some Apareiodon species (Pisces, Parodontidae). Cytologia 65:397-402.

Jorge LC and Moreira-Filho O (2000) Cytogenetic studies on Apareiodon affinis (Pisces, Characiformes) from Paraná River basin: Sex chromosomes and polymorphism. Genetica 109:267-273.

Jorge LC (2000) Distribuição geográfica de polimorfismos cromossômicos em Apareiodon affinis (Pisces, Characiformes). PhD Thesis, Universidade Federal de São Carlos, São Carlos.

Leite MF, Oliveira GA and Maistro EL (2000) Determinação da constituição cariotípica básica da espécie Apareiodon cf. affinis (Pisces, Characiformes, Parodontidae) coletados no Rio Sapucaí, MG. $46^{\circ}$ Congresso Nacional de Genética, Águas de Lindóia, SP, pp 50.

Levan A, Fredga K and Sandberg AA (1964) Nomenclature for centromeric position on chromosomes. Hereditas 52:201220. 
Margarido VP and Galetti Jr PM (1996) Chromosome studies in fish of the genus Brycon (Characiformes, Characidae, Bryconinae). Cytobios 85:219-228.

Margarido VP, Rosa R and Silva EB (2004) Descrição de um sistema de cromossomos sexuais ZZ/ZW em uma nova espécie de Apareiodon (Characiformes, Parodontidae) coletada no Rio Piquiri, Nova Laranjeiras, Paraná. X Simpósio de Citogenética e Genética de Peixes, Natal, RN, pp 72.

Martinez JL, Morán P, Garcia-Vázquez E and Pendás AM (1996) Chromosomal localization of the major and 5S rRNA genes in the European eel (Anguilla anguilla). Cytogenet Cell Genet 73:149-152.

Martins C and Galetti Jr. PM (1999) Chromosomal localization of 5S rDNA genes in Leporinus fish (Anostomidae, Characiformes). Chromosome Res 7:363-367.

Martins C and Galetti Jr. PM (2000) Conservative distribution of $5 \mathrm{~S}$ rDNA loci in Schizodon (Pisces, Anostomidae) chromosomes. Chromosome Res 8:353-355.

Moreira-Filho O, Bertollo LAC and Galetti Jr. PM (1980) Evidences for a multiple sex chromosome system with female heterogamety in Apareiodon affinis (Pisces, Parodontidae). Caryologia 33:83-91.

Moreira-Filho O, Bertollo LAC and Galetti Jr. PM (1984) Structure and variability of nucleolar organizer regions in Parodontidae fish. Can J Genet Cytol 26:564-568.

Moreira-Filho O, Bertollo LAC and Galetti Jr. PM (1985) Karyotypic study of some species of family Parodontidae (Pisces, Cypriniformes). Caryologia 38:47-55.

Moreira-Filho and Bertollo LAC (1991) Astyanax scabripinnis (Pisces, Characidae): A species complex. Brazil J Genet 14:331-357.

Moreira-Filho O, Bertollo LAC and Galetti Jr. PM (1993) Distribution of sex chromosome mechanisms in neotropical fish and description of a ZZ/ZW system in Parodon hilarii (Parodontidae). Caryologia 46:115-125.

Moreira-Filho O and Garavello JC (1994) Estudos de cúspides dentárias de seis espécies de Parodontidae e sua aplicação na sistemática desta família (Pisces, Characiformes). XX Congresso Brasileiro de Zoologia, Rio de Janeiro, pp 88.

Nomura H (1979) Caracteres merísticos e dados biológicos sobre o canivete Parodon tortuosus Eigenmann and Norris, 1900 do Rio Mogi-Guaçu, São Paulo (Ostheichthyes, Parodontidae). Rev Brasil Biol 39:451-456.

Pavanelli CS (2003) Family Parodontidae (Parodonts). In: Reis RE, Kullander SO and Ferraris Jr. CJ (eds) Check List of the Freshwaters of South and Central America. 1st edition. Edipucrs, Porto Alegre, pp 46-50.
Pendas AM, Moran P, Freije JP e Garcia-Vazquez E (1994) Chromosomal mapping and nucleotide sequence of two tandem repeats of Atlantic salmon 5S rDNA. Cytogenet. Cell Genet 67:31-36.

Pinkel D, Straume T and Gray JW (1986) Cytogenetic analysis using quantitative, high-sensitivity, fluorescence hybridization. Proc Natl Acad Sci 83:2934-2938.

Sato LR, Martins-Santos IC and Júlio Jr. HF (1998) Caracterização citogenética de espécies da família Parodontidae (Pises, Characiformes). VII Simpósio de Citogenética Evolutiva e Aplicada de Peixes Neotropicais, Londrina, pp A.34.

Sazima I (1980) Behavior of two Brazilian species of Parodontid fishes, Apareiodon piracicabae and A. ibitiensis. Copeia 1:166-169.

Schmid M (1980) Chromosome banding in Amphibia. IV. Differentiation of GC- and AT-rich chromosome region in Anura. Chromosoma 77:83-103.

Schneider TAA and Dias AL (2000) Dados cariotípicos em Apareiodon ibitiensis (Pisces, Parodontidae) coletados na bacia do Rio Tibagi, PR. $46^{\circ}$ Congresso Nacional de Genética, Águas de Lindóia, SP. pp 59.

Schneider TAA and Dias AL (2002a) Caracterização cariotípica de uma população de Apareiodon affinis (Characiformes, Parodontidae) da bacia do Rio Tibagi, PR: Provável ocorrência de um sistema cromossômico sexual múltiplo. IX Simpósio de Citogenética e Genética de Peixes, Maringá, pp 44.

Schneider TAA and Dias AL (2002b) Estudos cariotípicos em Parodon tortuosus (Characiformes, Parodontidae) provenientes do Ribeirão Três Bocas, PR. IX Simpósio de Citogenética e Genética de Peixes, Maringá, pp 45.

Sumner AT (1972) A simple technique for demonstrating centromeric heterochromatin. Experimental Cell Res 75:304-306.

Vicente VE (2001) Estudos citogenéticos e moleculares em Parodon hilarii e correlações com outras espécies da família Parodontidae (Pisces, Characiformes). PhD. Thesis, Universidade Federal de São Carlos, São Carlos.

Vicente VE, Jesus CM and Moreira-Filho O (2001) Chromosomal localization of $5 \mathrm{~S}$ and $18 \mathrm{~S}$ rRNA genes in three Parodon species (Pisces, Parodontidae) Caryologia 54:365-369.

Wasko AP and Galetti Jr. PM (2001) Molecular organization of 5S rDNA in fishes of the genus Brycon. Genome 44:893902 .

Associate Editor: Fausto Foresti 